\title{
VAPAUS, VELJEYS, TASA-ARVO - AIKUISKOULUTUKSEN KESTÄVÄT ARVOT POHJOISMAISSA?
}

$\mathrm{T}$ urussa 13.-14. toukokuuta järjestetty pohjoismaiden aikuiskasvatustutkijoiden kansainvälinen tapaaminen kokosi Turun yliopistoon lähes kaksisataa aikuiskoulutuksen pohjoismaista tutkijaa teemalla "Adult education - Liberty, Fraternity, Equality?”. Järjestäjänä konferenssissa toimivat Turun yliopiston Elinikäisen oppimisen ja koulutuksen tutkimuskeskus (CELE), Suomen aikuiskasvatuksen tutkimusseura sekä Kasvatusalan valtakunnallinen tutkijakoulu (KASVA). Konferenssi muodostui key note -esitelmistä, network-ryhmistä, joissa esitettiin noin 60 tutkimuspaperia, sekä paneelista, johon osallistui kahdeksan aikuiskoulutuksen tutkijaa.

Konferenssin avannut professori Risto Rinne, joka kysyi, miltä maailma näyttäisi ilman Ranskan vallankumousta. Tuon vallankumouksen teesit, vapaus, veljeys ja tasa-arvo, ovat elähdyttäneet yli kaksi vuosisataa kansakuntia ja kansalaisia maailman herruutta tavoittelevia valtoja ja säätyläisvaltaa vastaan. Tämän aatteen yhtenä kantajana voidaan pitää niitä valistukseen kytkeytyviä virtauksia, jotka kohosivat ympäri Pohjolaa 1800-luvulta lähtien kansanvalistuksen, vapaan kansansivistystyön ja aikuiskasvatuksen lippujen alla.

Professori Anja Heikkinen tarkasteli alustuksessa aikuiskasvatustutkimuksen tilaa Suomessa ja Pohjoismaissa. Hän näki aikuiskasvatustutkimuksen viimeaikaisen historian yhdenlaisen "epäpolitisoitumisen" vaiheena, jossa aikuiskasvatusta on alettu tarkastella yhä enemmän alisteisesti, pelkkänä kehittämisenä ja human resource -asiana. Tätä kautta intellektuaalisesti virittynyt perustutkimus on ollut fragmentoitumassa. Heikkinen peräsikin vapaata ja kriittistä otetta tutkimukseen.

Professori Kjell Rubenson University of British Columbiasta tarkasteli luennossaan syitä siihen, miksei aikuiskoulutukseen ole investoitu riittävästi ja miksei ns. pareto-optimaali toteudu elinikäisen oppimisen saralla. Erityisen vähän aikuiskoulutuksen piiriin osallistuu työntekijöitä, joilla on ennestään alhainen koulutustaso. Rubenson mainitsi, että nämä työntekijät eivät saa vastaavaa rahallista hyötyä kouluttautumisestaan. Palkat eivät nouse samassa suhteessa osaamiskompetenssin nousun kanssa. Pohjoismaissa osallistuminen aikuiskoulutukseen on laajempaa kuin muissa OECD-maissa ja lisäksi Pohjoismaiden aikuisväestöä luonnehtii suhteellisen homogeeninen hyvä lukutaito. Verraten tasaisen lukutaidon ohella Pohjoismaita leimaa verraten tasainen tulonjako. Pohjoismaat erottuvat tilastollisesti täysin omana ryhmänään muiden OECD-maiden joukossa. Rubenson nimeääkin pohjoismaisen hyvinvointivaltiomallin epäoikeudenmukaisuuksia tasoittavan vaikutuksen yhdenlaiseksi G-faktoriksi, joka näkyy sekä tuloerojen että lukutaito- ja koulutuserojen kapeutena.

Professori Marianne Horsdal Etelä-Tanskan yliopistosta pohti luennossaan investointia inhimilliseen pääomaan ja elinikäiseen oppimiseen. Hän toi esille mielenkiintoisen havainnon siitä, ettei inhimillinen pääoma sinällään ole tuottavaa, vaan saavutettuja tietoja ja taitoja pitää voida ja osata käyttää. Niiden käyttö pitää sallia työpaikoilla. Formaali koulutus antaa yksilölle edellytyksiä hyödyntää työelämässä myös informaalisti opittuja asioita. Tulevaisuudessa ainoastaan joka seitsemännen työpaikan ennakoidaan olevan sellainen, jossa kykenee toimimaan pelkän peruskoulutuksen varassa. Vaikka inhimillisen pääoman arvon ennakoidaan kohoavan työnantajien etsiessä palvelukseensa yhä osaavampaa työvoimaa, investointi inhimilliseen pääomaan nähdään usein riskisijoituksena. Investointia esimerkiksi laitteistoon pidetään pysyvämpänä kuin investointia ihmisiin, jotka voivat liikkua vapaasti, vaihtaa työpaikkaa tai jopa maata.

Professori Agnieszka Bron Tukholman yliopistosta analysoi viiltävän terävästi Ranskan vallankumouksen kolmen "toteemin”, vapauden, veljeyden ja tasa-arvon, kantavuutta aikuiskasvatuksen ohjelmassa aina näihin päiviin saakka. Hän esitteli myös Ruotsin oppimiskeskuksia, jot- 
ka on suunnattu koko väestölle ja joiden tavoitteena on tuoda oppiminen lähemmäksi ihmisiä joustavin muodoin hyödyntäen teknologiaa, erilaisia projekteja ja yhteistyötä eri instanssien välillä. Bronin mukaan oppimiskeskusten ideaaleina voidaan perimmältään nähdä vapauden, veljeyden ja tasa-arvon tavoittelu. Jaloista aatteista huolimatta ne houkuttelevat huomattavasti enemmän naisia kuin miehiä korostaen sisaruutta veljeyden ohi. Pitäisikö miehet saada tasa-arvon nimissä mukaan aikuiskoulutukseen vai onko heillä vapauden nimissä oikeus jättäytyä siitä pois?

Tutkija Sigvard Tøsse (Norwegian University of Science and Technology) tahtoi analyyttisesti eritellen tuoda selkeästi esille tasa-arvon käsitteen moniulotteisuuden. Hän korosti sitä, että osallistumiseen ja mahdollisuuksiin liittyvä equality on aivan eri asia, kuin oikeudenmukaiseen kohteluun ja hyvän oikeudenmukaiseen jakoon liittyvä equity. Hän konstruoi norjalaisen tasaarvon sosiaalisesti ja poliittisesti määrittyvän historiallisen kertomuksen, millä osoitti, että oikeudenmukaista tasa-arvoa voidaan tavoitella sekä mahdollisuuksien tasa-arvon että tasoittavan eriarvoisuuden kautta.

$\mathrm{P}$ äivien yhdeksän network-ryhmää kattoivat monipuolisesti aikuiskasvatuksen ja -kou lutuksen lavean kentän. Useimmat ryhmät olivat aidosti yhteispohjoismaisia; kaikkiaan parikymmentä alustusta pidettiin ulkomaisin voimin. Myös Latvia ja Yhdysvallat olivat edustettuna. Ilahduttavan monet esitykset nivoutuivat eri tavoin päivien yleisteemoihin. Tasa-arvon problematiikkaan pureuduttiin ryhmissä "Gender and Equality in Adult Education" (pj. Annukka Jauhiainen ja Tarita Ruoholinna) sekä "Exclusion and Inclusion in Lifelong Learning and Comparative Research in Adult Education” (pj. Joel Kivirauma ja Kirsi Klemelä). Tämä ryhmä oli myös kaikkein pohjoismaisin. Ryhmässä ”Lifelong learning -ideology and reality?” (pj. Mikko Aro) pureuduttiin kahdeksan esityksen voimin paikoin hyvinkin kriittisin äänenpainoin elinikäisen oppimisen poliittis-ideologisiin tavoitteisiin sekä ihmisten arkitodellisuuteen. Helene Ahl Jönköpingin yliopistosta problematisoi perinteistä tapaa käsitteellistää ja tutkia aikuisten opiskelumotivaatiota ja Jukka Tuomisto Tampereen yliopistosta tarkasteli aikuiskoulutuksen tasa-arvotavoitteen toteutumista laajassa historiallisessa perspektiivissä.

Hyvin erilaisista näkökulmista aikuiskoulutuk- sen ja työelämän välisiä kytkentöjä käsiteltiin ryhmissä "Transition from Education to Work” (pj. Tero Järvinen ja Jarkko Mäkinen), ”Learning at Work” (pj. Laura Helle ja Petri Haltia) ja ”Development interventions and learning” (pj. Hanna Toiviainen). Ryhmässä "Expanding and Changing Higher Education" (pj. Arto Jauhiainen) kuultiin mm. kaksi alustusta aikuisille suunnatuista maisteriohjelmista Tanskassa. Oma ryhmänsä oli myös yrittäjyyden teemalle ”Entrepreneurship and adult education” (pj. Paula Kyrö).

Vapaudesta, veljeydestä ja tasa-arvosta puhuttaessa ei tietenkään voida unohtaa vapaata sivistystyötä. Ryhmässä "Liberal Adult Education in changing society” (pj. Petri Salo) käsiteltiin elinikäisen oppimisen tavoitteita ja merkityksiä suomalaisissa ja brittiläisissä kansalaisjärjestöissä, vapaan sivistystyön skenaarioista sekä monimuoto-opiskelua aikuisten arjessa.

Päätöspaneelissa väiteltiin Rinteen johdolla aikuiskoulutuksesta suhteessa vapauteen, veljeyteen ja tasa-arvoon. Mukana olivat Kjell Rubenson, Sigvard Tøsse, Marianne Horsdal, JonTorfi Jónasson Islannista, Tarja Tikkanen (Rogaland Research), Anja Heikkinen, Juha Suoranta ja Heikki Silvennoinen. Paneeli ei löytänyt yksimielisiä ratkaisuja monimielisiin ongelmiin. Kun Tarja Tikkanen peräsi rakentavaa aikuiskasvatustutkimusta, totesi Juha Suoranta, ettei Suomessa juuri ole radikaalia aikuiskasvatustutkimusta. Heikki Silvennoisen tärkeä viesti oli, ettei aikuiskoulutus ole sama kaikille, vaan merkitsee eri ihmisryhmille täysin eri asioita. Pääsääntöisesti tutkimuksen taivaalla nähtiin painostavia tummia pilviä, jos ei peräti sadetta, mutta useat olivat näkevinään myös auringon pilkahduksia.

Konferenssin juhlavin hetki koettiin, kun iltajuhlassa Suomen aikuiskasvatuksen tutkimusseura ojensi Anja Heikkisen ja Petri Salon käsin Jukka Tuomistolle hänen juhlakirjansa Aikuiskasvatuksen tutkimuspolut. Myös konferenssin tiimoilta on tarkoitus julkaista kirja.

Seuraava pohjoismainen aikuiskasvatustutkijoiden konferenssi hakee paikkaansa lähinnä Örebrosta tai Kööpenhaminasta.

Tähän mennessä laajimman Pohjoismaiden aikuiskasvatuksen tutkijoiden konferenssin onnistuneiden järjestelyjen takana uurasti ennen muuta suuri joukko CELEn väkeä, josta päävastuun kantoivat Kati Lahti ja Tuuli Kaunisto.

Risto Rinne ja Arto Jauhiainen 